\title{
Comparative Study of Strengthening National Defense Education in Colleges in Our Country under the New Situation
}

\author{
Take National Defense Education in Western Countries as Reference
}

\author{
Zhenjing Cai \\ Zhejiang Shuren University \\ Zhejiang, China, 40005
}

\begin{abstract}
In recent years, the international situation around China has shown some new development patterns. Our national security is facing increasingly serious challenges. Under such new situation, we must effectively improve college students' awareness of defense security through strengthen national defense education in colleges. Taking this as the starting point, the thesis compares the experience of national defense education in China and Western colleges and proposes specific countermeasures and suggestions to the problems our colleges' national defense education facing, so as to promote the progress of our national defense education actively and prudently.
\end{abstract}

Keywords-National Security; Colleges; National Defense Education

\section{INTRODUCTION}

In recent years, the security situation around China has become tense suddenly. Sino-Indian border conflicts, SinoPhilippine South China Sea disputes, Sino-Vietnam Xisha Islands resentments, and Sino-Japanese field distractions have fully shown in 2012. Especially on the issue of the sovereignty of the Diaoyu Islands, the disputes between China and Japan have deepened since Japan persisted in purchase the island. Along with the creation of the East China Sea air defense zone in Nov.2013, the relationship between China and Japan has become tenser than ever. On the first day of the lunar year of horse 2014, Chinese air force dispatched SU-30 fighter to expel Japanese F-15 fighter from China air defense zone, which aggravated the worries about that the military conflicts between China and Japan would broke out in Jiawu year from the outside world. Under such serious international situation, the national defense awareness of the people should be strengthened urgently, especially national defense education in college. It is because college students are the hard core of a country and a nation, which represent the future of a country and a nation. If they have a strong sense of national defense and crises, the country and the nation will be long standing and ever thriving. How to strengthen national defense education in colleges at present? In face of this realistic problem, the writer compares the national defense education in China and Western colleges, in order to find a new way for the national defense education in China.

\section{AnAlysis on the NeCESSity of National DefEnSE EDUCATION IN COLLEGES}

\section{A. The Requirements of Developing National Defense}

After the Second World War, the forms of the world warfare and military theories have undergone great changes. The future war is not only the competition of national manpower, financial and material resources, but also the competition of science and technology. This is best proved in the fact that all countries employed the most advanced technology into defense equipment and defense construction. For example, the design and manufacture of the strategic missile of our country have used the most advanced technology in China. Therefore, in the modern warfare, the one who obtains advanced science and technology has the military advantage. Cultivate military personnel only count on the military colleges won't meet the needs of the military since there is a high cost and long training period. From the specific national situation of our country, colleges can be regarded as the base to cultivate backup military personnel. Therefore, strengthen the national defense education and promote college students' awareness of national defense will lay firm foundation for them to build and protect our motherland in the future.

\section{B. The Requirements of Promoting Economic Modernization}

The economic modernization not only needs the support of material resources, but also spiritual power. The awareness of national defense is a kind of spiritual power taking patriotic feelings, national responsibilities and revolutionary heroism as the core. Permeating and blending the awareness of national defense into the minds of the public through certain manners will turn into great combat power in military and tremendous productivity in economic construction. The construction of national defense and economy cannot be separated from each other. National defense construction must take economic construction as the base, without which the national defense construction will be like water without a source and a tree without root; on the contrary, without the guarantee of suitable national defense capabilities, the development of economic construction won't last long either. College students are the successors and vital force of the 
construction of China's socialist economic modernization. Attaching importance to the cultivation of college students' awareness of national defense is the concentrated reflection of "representing the demands of Chinese advanced productivity development" in the field of education. It is directly related to the historical mission of the sovereignty and territorial integrity of the motherland, and the flourishing of spirit of patriotism. It is a great project that represents the advanced direction of Chinese civilization, which directly related to the long-lasting prosperity of the country and the great rejuvenation of the Chinese nation. It is also the reliable warrant of representing the fundamental interests of the people. Therefore, carrying out national defense education and cultivating college students' awareness of national defense will inspire the sense of responsibility, urgency and mission among college students, and promote the economic construction of our country effectively.

\section{The Requirements of Realizing the Fundamental Target of Higher Education}

The fundamental target of higher education is to help college students developing their complete personalities besides mastering the academic knowledge. National defense education relies on the subject system of military science. Modern military science is a comprehensive science with a wide range and rich content. The antagonism, ruthlessness and complexity of military conflicts bred the military thinking with the character of creativity. Therefore, national defense education could improve the practical abilities of college freshmen and widen their thoughts to make students think and solve problems from different aspects. In this regard, learning military science is not only beneficial to widen the scope and expand knowledge, but also beneficial to break think mode of academic study, broaden the thinking space, and improve creativity and comprehensive thinking abilities, so as to further improve the adaptability of college students. In addition, national defense education could also cultivate college students' strong wills. The regulations of military education on the standard and quality of education and training are based on the objective requirements of certain warfare. Therefore, military education must rely on the compulsory force, honing army men under hard and complex environment, reaching the specific standard of actual combat through super tense training, and regulating their own behavior strictly abide by disciplines in every aspects of study and training. This compulsory is beneficial to the educates to hone themselves under hard situation and to set up correct viewpoint on hardship and happiness, so as to effectively nourish their indomitable will, firm perseverance and the spirits of unafraid of hardships.

\section{The Present Situation and Shortage of College NATIONAL DEFENSE EDUCATION IN CHINA}

China government always attaches great importance on the college national defense education. Under the macro-control by our government, colleges in China have widely established the military training system since long time ago. Some colleges also offer courses on teaching military theory. Along with the issue of the National Defense Education Act of the People's Republic of China on April 2001, national defense education was officially brought into the legal track ${ }^{1}$. National Defense Education Act has made clear definition of national defense education. In the fifth article of the National Defense Education Act, national defense education is defined as the education for all. Every Chinese citizen has the right and obligation to receive national defense education. Strengthening and popularizing national defense education is the duty of the whole society. It also specially emphasizes the specific responsibilities of colleges in national defense education in the fifteenth article of the National Defense Education Act. Colleges should carry out national defense education combining classroom teaching with military training. On this basis, CPC Central Committee, the State Council and Central Military Commission issued the Opinions of the National Defense Education under New Situation in 2011, further provided guidance to the national defense education in colleges ${ }^{2}$. The issue of the series of regulations and policies has raised the boom of national defense education in colleges. Until today, 157 colleges throughout the country have been experimental colleges of national defense education, most of which have established military teaching and research office.

Under the support of our government, the development trends of national defense education in our colleges are rather optimistic, however, there are also some shortages. First, the teaching management mechanism in college national defense education is not sound. This is mainly because many colleges have different recognition on the importance of national defense education, which leads to the fact that the comprehensive education of colleges cannot be fully performed. What is worse, in the development process of many colleges, they think that it is enough to carry out national defense education only in military colleges. There is no need to invest too many manpower and material resources into national defense education for local colleges, but only to carry out military training and offer courses on military theory. This directly leads to the insufficiency of the teaching management mechanism in national defense education in many colleges. Even some military teaching and research offices established have been remain in name only, and couldn't play their supposed function ${ }^{3}$. Second, the setting of the college national defense education course is unreasonable. In the process of national defense education, many college only define national defense education as an optional course, and students could choose whether to learn or not by their own. This leads to the fact that the aim of making every student learns national defense education could be implemented effectively. In the setting of the course, there is no distinction between the major and the minor one and a lake of systematic, which will great reduce the effectiveness of national defense education ${ }^{4}$. What's more, the teaching methods of national defense education are not various. In the process of national defense education, many colleges only employ classroom theory teaching and extracurricular military training, which directly made many students lose the interests of learning in national defense education because of the stereotyped teaching mode. This is harmful to the cultivation of students' awareness of national defense. 


\section{EXPERIENCES AND INSPIRATIONS OF NATIONAL DEFENSE EDUCATION IN WESTERN COUNTRIES}

Many western countries have attached great importance on their national defense education like our country. During the practice, they have many heuristic experiences that worth our study.

\section{A. Unified Recognition and Complete Mechanism}

In the western world, although there are many differences on social system, ideology, culture, tradition, and national interest, there is a high unity of recognition on the importance of college national defense education. The Swiss Government believes that college students are not only the master of the country, but also the indispensable human resource for protecting the country, thus it attaches great importance on military training and national defense knowledge education for college students5. Russia Government maintains that national defense education should take college students as the focus. France Government proposes that college students are the major target of national defense education. The US Government even believes that the competition in the future is the competition of nation and national defense qualities, as well as the competition of talents, which relies on the cultivation of the youth. Whether the US has competitiveness or not is highly dependent on college education, especially on the cultivation of military personnel among college students.

Based on the great attention to college national defense education, western countries have established a complete teaching and management mechanism in the process of college national defense education according to their specific national conditions, which ensured the effective implementation of national defense education in colleges. In the colleges of Britain and the US, there are special military training organizations to train military personnel, such as the US Reserve Officers Training Corps, Britain Military Training Corps, Israel Gardner Organization, and India National Students and Soldiers Training Corps ${ }^{6}$. Some other countries carried out national defense education through establish national defense education or military training management organizations. For example, in the US, under the direct leadership of the military, army, navy and air forces have established 531 Reserve Officers Training Corps in total in local colleges, which specialized in the military training and national defense education for the reserve officers of the certain military service. In Russia, there are military teaching and research offices in almost all non-military colleges. There is military training department in some colleges, which specialized in the military training and the teaching of military course in colleges.

\section{B. Important Position and Rich Contents}

In the arrangement of the specific course of national defense education in colleges, many western countries have taken national defense education course in a very important position. In order to strengthen national defense education of the college students, Russia Government lists military as a compulsory course in colleges. In addition to open optional military courses commonly, US colleges have also combined national defense education with the teaching of other subjects, especially history and geography, making national defense education form a complete system and further strengthening the cultivation of students' comprehensive abilities. In recent years, in order to improve its international competitiveness, the US has undergone comprehensive reforms against the shortages in the courses like natural science, mathematics, engineering and so on in local colleges, so as to meet the needs of the changes in world military structure and modern warfare under advanced technology. This has laid the firm foundation for the effective implementation of national defense education in the $\mathrm{US}^{7}$.

\section{Various Forms and Reasonable Arrangement}

In the implementation process of national defense education in colleges, the western countries have employed different reasonable teaching methods and received fine teaching results. In addition to set classroom teaching and military training, the US colleges also conducted national defense education through vivid platforms such as films, television programmers, drama and so ${ }^{8}{ }^{8}$. French colleges stipulated that college students should participate in social activities annually at regular intervals such as national defense education day for the public held by armed fores ${ }^{9}$. In order to strengthen college students' national defense awareness, Britain has opened national defense education program in local newspapers, magazines, radio stations and television to create a fine social environment for national defense education. These activities are easy to be accepted because they are very interesting and suit the psychological characteristics of college students' growth. As a result, there will be good results in the practice of national defense education in colleges.

\section{Countermeasures AND Suggestions For Strengthening NATIONAL DEFENSE EDUCATION IN OUR COUNTRY}

It is beneficial to learn from other's experiences. Through the deep study on the successful experiences of national defense education in western countries' colleges, we can learn from those experiences based on our national situation, propose specific countermeasures and suggestions to the problems facing in front of national defense education in our colleges.

\section{A. Improve the Management System}

We must consider the problems of shortages in the teaching and management system of national defense education in our colleges thoroughly. In this regard, we should start form the leaders of colleges, making them reach consensus on the importance of college national defense education. It is because college leaders play a decisive role in college national defense education: they are the leaders, as well as educators ${ }^{10}$. With their supports, we should construct the sound teaching and management institutions for national defense education in time, for example, set specific teaching and research offices for national defense education, supervising and guiding the implementation of scientific research activities of national defense education through these institutions, and solving the difficulties and problems in the process of teaching. In the meantime, a reward and 
punishment mechanism should also be made in college national defense education. Inspect the actual effects of teaching through teaching and research offices for national defense education, rewarding advance workers and punishing the backward, so as to form a fine teaching environment of taking it as a glory and credit to emphasize teaching and research offices for national defense education.

\section{B. Perfect Course Arrangement}

In course arrangement, we should place teaching and research offices for national defense education in an indispensible position because of its importance, equal to the compulsory course of ideological and political. If students fail in the test of national defense course during their study in colleges, they cannot graduate from the college or get certain degree. This will improve students' attention to the course of national defense in college objectively and push them to devote more time and effort in the learning of national defense both in class and in daily life. In the arrangement of certain course, we must combine essential characteristics of national defense education with the resources of college education, take patriotic education as the core, and supplement with a series of courses like military, history, geology, law, philosophy and politics, PE and so on, so as to improve national defense education into a systematic course that has distinctions between the important and the lesser one. This is also the inevitable requirements of the development trends at home and abroad to college national defense education.

\section{Enrich the Teaching Methods}

In the teaching methods of college national defense education, we must make certain reforms to meet the developing trends of the times and the students' psychological characteristics of growth. In addition to classroom teaching of military theory and extracurricular military training, we should carry out explicit and implicit national defense education by using college and social Medias. In college, we can spread national defense information through broadcast, WeChat, and network; organize performances on national defense through students' associations; play national defense education films in college cinema; and organize national defense knowledge contest through the college Communist Youth League. In society, we can broadcast current news on national defense through newspaper, magazines, radio stations and television, report military news, promote the spirit of patriotism, and build a fine environment for national defense culture. Through those explicit and implicit teaching methods, national defense knowledge and information will appear everywhere in students' life and study. Such method won't cause students' antipathy, but inspire their interests in study, help them form good awareness of national defense, and achieve the fundamental goal of college national defense education.

\section{REFERENCES}

[1] Huo Yonggang, Thinking on Strengthening National Defense Education [J], Journal of CPC Taiyuan Party School, 2001(1).
[2] Liu Jin, National Defense Education is the Foundation of Cultivating Qualified Personnel in Common Colleges---Methods and Results of National Defense Education in Xi'an Eurasia University [J], Journal of Xi'an Eurasia University, 2012(2).

[3] Song Jun, Present Situation and Countermeasures of College National Defense Education [J], Education Science, 2001(7).

[4] He Yiqing, Existing Problems and Countermeasures of National Defense Education [J], Creation, 2001(3).

[5] Jiang Yajing, Introduction and Inspiration of Foreign National Defense Education [J], Journal of Jilin Radio and Television University, 2008(2).

[6] Wang Hezhong, How to Carry out National Defense Education in Developed Countries [J], Current Affairs, 2002(1).

[7] Zhu Fangzhuan, Characteristics and Inspirations of National Defense Education in Foreign Schools [J], Industrial and Science Tribune, 2008(12).

[8] Zhang Liju, Comparative Study on National Defense Education in Common Colleges in China and Abroad [J], Education Exploration, 2007(3).

[9] Meng Li, Glimps on the Characteristics of Foreign National Defense Education [J], National Defense, 2004(5).

[10] Tan Huajun, Thinking on Improving the Results of National Defense Education [J], National Defense, 2012(4). 